\title{
The experience of Arab workers working in Turkey: Qualitative study
}

\author{
Dalya ALNAJJAR ${ }^{a}$, Ahmad ALSAMAN ${ }^{b}$ \\ a Corresponding author, Sakarya University, alnajjardalia@gmail.com Orcid:0000-0003-2035-8918 \\ b Sakarya University Orcid: 0000-0001-9606-8170
}

ARTICLE INFO
Research Article
Received 4 July 2020
Received in revised form
23 October 2020
Received in revised form
29 October 2020
Accepted 30 October
2020

\begin{abstract}
This paper investigates the experience of foreign workers (FWs), essentially Arabs, in the workplace in Turkey with a focus on two major aspects, the first aspect is discrimination and bias that FWs face in the workplace in terms of regulations, task assignment, and relationship with colleagues. While the second aspect is the preference of FWs to work in an entrepreneurial career and the preference of working with a non-Turkish boss. The study took a qualitative approach to reach its finding, 17 people were interviewed individually, and two focus groups took place. The interviews were coded and classified through (consider.ly) platform to find the main trends and common points of discussion. The analysis of the collected data shed the light on one of the challenges that blue-collar FWs face when they start working in Turkey which we named as "internal-discrimination". We define "Internal discrimination" as a type of discrimination that describes the exploitative and discriminatory practices that some people engage in against people from the same country due to a lack of specific skills in an abroad workplace. We noticed that the major factors that encourage this behavior are the language barrier as many FWs lack language skills as well as the desperate need for money to sustain a living. Internal discrimination seems to affect the experience of FWs in Turkey significantly negatively. The analysis found no discrimination; however, the light was shed on a lot of dishonesty and exploitation.
\end{abstract}

Key Words: Foreign workers, work permits, workplace challenges, immigrants.

\author{
MAKALE BILGILERi \\ Araştırma Makalesi \\ Geliş Tarihi 4 Temmuz \\ 2020 \\ Revizyon 23 Ekim 2020 \\ Revizyon 29 Ekim 2020 \\ Kabul tarihi 30 Ekim 2020
}

Türkiye'de Arap çalışanların deneyimi: Nitel çalışma

\begin{abstract}
Özet
Bu makale, ağırıklı olarak Araplar olmak üzere yabancı işçilerin (Yi'ler) Türkiye'deki işyerlerindeki deneyimlerini iki ana konuya odaklanarak incelemektedir; ilk yön, Yílerin işyerinde düzenlemeler, görev atamaları ve görev atamaları açısından karşılaştıkları ayrımcılık ve meslektaşlarla ilişki. İkinci yön ise Yi'lerin girişimcilik kariyerinde çalışma tercihi ve Türk olmayan bir patronla çalışma tercihidir. Çalışma, bulgusuna ulaşmak için nitel bir yaklaşım benimsedi, 17 kişiyle bireysel olarak görüşüldü ve iki odak grubu oluşturuldu. Görüşmeler, ana eğilimleri ve ortak tartışma noktalarını bulmak için (consider.ly) platformu aracılığıyla kodlanmış ve sınıflandırılmıştır. Toplanan verilerin analizi, mavi yakalı Yi'lerin Türkiye'de çalışmaya başladıklarında karşılaştıkları ve "iç ayrımcılık" adını verdiğimiz zorluklardan birine ışık tuttu. "İç ayrımcılık" I, yurtdışındaki bir işyerinde belirli becerilerin bulunmaması nedeniyle bazı kişilerin aynı ülkeden kişilere karşı uyguladıkları sömürücü ve ayrımcı uygulamaları tanımlayan bir ayrımcılık türü olarak tanımlıyoruz. Bu davranışı teşvik eden ana faktörlerin dil engeli olduğunu fark ettik, çünkü birçok Yi'de dil becerilerinin yanı sıra hayatını sürdürmek için çaresiz paraya ihtiyaç var. İç ayrımcılığın Türkiye'deki FW deneyimlerini önemli ölçüde olumsuz etkilediği görülmektedir. Analiz hiçbir ayrımcılık bulmadı; ancak, birçok sahtekarlık ve sömürü üzerine ışık tutuldu.
\end{abstract}

Anahtar Kelimeler: Yabancı işçiler, çalışma izinleri, işyeri zorlukları, göçmenler.

\section{Introduction}

The political, geographical, and economic positions of Turkey during the past decade made it a designated destination for different groups of people, from refugees to immigrants to tourists. Currently, Turkey is home to 5.7 million migrants from 192 countries according to the Turkish Statistics Institute (Turkish Statistics Instutute, 2019). Despite the existence of large numbers of people from different cultures, one of the most popular beliefs among Turkish citizens on immigrants and foreigners is that they are in Turkey to replace them in their jobs and increase unemployment (Araci, 2018) (Tören, 2018). The world civilizations each built a culture that represents their beliefs, values, and tradition, one puzzling product of these cultures is the "othering" behavior. Considered one of the 21st century main dilemmas, othering is known to be a fuel for disputes when different cultures clash. (Atik, 2012), thus, the situation in Turkey is very appealing to research as it is inhabited by different groups who have different cultural backgrounds.

Examining the socio-political climate and trends in Turkey, it is realized that Turkey is transformed into a migrants country (Rittersberger-Tilıç, 2015) and this raises a lot of questions in different relevant fields. One of the main challenges that Turkey faces as a host for a considerable number of refugees and immigrants according to the world bank policy note (2016) was "How to maximize the social and economic benefits of the refugee presence for host communities and the Turkish economy as a whole?".

In this paper, we investigate a different aspect of the social and economic lives of Arab workers in Turkey, by studying their motives and experiences at work. The paper does not focus on refugees instead it focuses on other categories of foreigners who come to Turkey to study or work.

\section{Background}

In the context of employment and work, there is evidence that the Turkish labor market has segmentation between the formal and informal sector (Aydin, 2009), foreigners are more engaged in the informal sector because of the difficulty of obtaining work permits in Turkey (Rittersberger-Tilıç, 2015). According to the Turkish statistics center, 2018, the unemployment rate is realized at 10.6 percent, decreased from the 2017 rate by a .7 percent point decrease. The youth unemployment rate, however, witnessed an increase by .7 percent to be at 20.6 percent. On the other hand, the rate of unregistered employment was realized as $35.1 \%$ at a .5 percent point decrease. Turkstat defines unregistered employment as the ratio of persons working without any social security relating to the main job.

The General Directorate of International Labor Force (The General Directorate of International Labour Force, 2017) identifies Foreigner as the person, who is not a citizen of the Republic of Turkey. It identifies work permits as the official document which is issued by the Ministry and which gives the foreigner the right to work and reside in Turkey within the validity period.

There are three main types of work permits: definite, permanent, and independent work permits. The table hereunder shows the number of permits given to foreigners by types and years 2011-2017. 
Table 1. The number of permits given to foreigners by types and years 2011-2017.

\begin{tabular}{|l|l|l|l|l|}
\hline Year & Definite permits & Permanent permits & Independent & Total \\
\hline 2011 & 17,318 & 132 & 16 & 17,466 \\
\hline 2012 & 32,191 & 79 & 9 & 32,279 \\
\hline 2013 & 45,721 & 93 & 9 & 45,823 \\
\hline 2014 & 52,197 & 95 & 3 & 52,295 \\
\hline 2015 & 64,402 & 115 & 4 & 64,521 \\
\hline 2016 & 73,410 & 115 & 24 & 73,549 \\
\hline 2017 & 87,150 & 19 & 13 & 87,182 \\
\hline
\end{tabular}

In a span of seven years, the total number of work permits has increased by nearly five times. We can also realize from the table that the numbers of permanent and independent work permits are very low. The number of permanent permits had decreased from 115 in 2016 to only 19 in 2017.

In 201743.3 percent of the permits were given to women which is the lowest percentage across the seven years (Balkir \& Böcker, 2015). The highest percentage of 62 percent was recorded in 2013.

İçduygu noted that more policies need to be directed towards facilitating the refugees' access to formal work. He emphasized the significance of the availability of access to education and training opportunities for refugees (içcuygu, 2013). Prior to 2013, Turkey had only one law regarding foreigners which was the 1994 Regulation on Asylum law which institutionalized the management of migration and asylum (içduygu, 2013). In 2013 the Turkish Parliament adopted new laws which govern The Turkish labor migration legislation is along with several acts, including the recently adopted Law on Foreigners and International Protection (Law No. 6458 from 2013), the Law on the Work Permit for Foreigners (Law No. 4817 from 2003), Labor Law (Law No. 4857 from 2003), Social Security and Universal Health Insurance Law (Law No. 5510 from 2006), Citizenship Law, (Law No. 5901 from 2009), Trade Unions and Collective Labor Agreements (Law No. 6356 from 2012) and Occupational Safety and Health (Law No. 6331 from 2012). The adoption dates of these acts show that the majority of national labor migration legislation is recent, mainly because of the pressure by the European Union and the Council of Europe on Turkey concerning the EU accession negotiation process.

\section{Literature Review}

Most of the studies regarding foreigners are focused on the integration of refugees (iççuygu, 2016; Kuyumcu \& Kösematoğlu, 2017; Goksel, 2018). Some studies focused on the effects of immigration on the labor market such (Borjas, Freeman, \& Katz, 1996; Cohen-Goldner \& Paserman, 2011; Akgunduz, Berg, \& Hassink, 2015; Rittersberger-Tilıç, 2015; de Castro, Fujishiro, Aweitzer, \& Oliva, 2016; Fakih \& Ibrahim, 2016; Ceritoglu, Yuncule, Torun, \& Tumen, 2017; Kuyumcu \& Kösematoğlu, 2017; Araci, 2018).

A study by De Castro, Fujishiro, Aweitzer, \& Oliva (2016) attempted to design a model of immigrant workers' experience at work. One of the main aspects of the model was work organization which they defined as how tasks and jobs are designed. In their paper, they discuss the impact of work design on the experience of FWs. Another dominant discussion in the literature is regarding the dichotomy of skilled and unskilled immigrants ( Favell, Feldblum, \& Smith, 2007). A study by Ceritoglu, Yuncule, Torun, \& Tumen (2017) investigated the impact of the Syrian refugees on the native labor market in Turkey. In their research they discussed how forced immigration can provide cheaper unskilled labor and even though most of the refugees do not have a work permit, they join the market and impact the native labor. The researchers claim that the Syrian refugees caused many of the natives to lose their jobs. They also claim that Turkish Citizens' employment probability was negatively affected by the incoming Syrian refugees. However, statistics show no impact on the wages of Turkish citizens. This research is eye-opening about the bias in academia in such local issues when discussed out of context, in one hand, there is no enough background data that was provided to introduce the context and on the other hand, the paper is an example of fear-mongering which would affect the economic behavior of the labor market in turkey.

The size of the unregistered market in Turkey has significantly grown with the immigrant's inflow Which paved the way for the employers to keep the wages for the unskilled native workers low. One of the main sectors in which many undocumented foreign works is the tourism sector. The humanity issue of "Undocumented foreign worker" is a pressing phenomenon and policies should be developed to support the Turkish for economy, in addition to ensuring the dignity of foreign workers. The work permits legislation is one of the policies used to encounter the challenge. In conclusion, it can be said that Turkey has to revise its legislation related to foreign workers (Yildiz, 2007).The inflows of immigrants impacted the informal market which led to employment losses among natives in Turkey, especially in labor-intensive works. The main results of these phenomena are represented in a price decrease for some products as the cost of labor had decreased. Overall, these results suggest that the immigrant's inflows have placed new costs on the living standards of the Turkish community (Tumen, 2016). Research by Tören (Tören, 2018) discussed that Turkish citizens from the working class or from the middle class accuse Syrians of worsening the working or living conditions.

\section{Research Gap}

Most of the studies discuss the topic from the discrimination and biases of the employers of WFs, with a focus on Syrian and Iraqi refugees neglecting the rest of the minorities and immigrants, students who work to support themselves, some studies focused on the illegal and undocumented FWs. Our paper is attempting to include a more varied sample of foreign workers in Turkey. We are also addressing one of the rare topics when studying FWs, which is the avoidance of FWs to work with Turkish employers or preferring a foreigner manager and we also attempt to research FWs experience from their own point of view.

\section{Research Significance}

There is no research on the preference of FW to work with non-Turkish employers or direct managers. Most research focuses on either the formal or the informal work of refugees. Besides, there's not enough research regarding foreign workers in general, and there is a trend in researching the refugees, immigrants, and asylum seekers mainly. The research also introduces the concept of "internal discrimination" which is widespread in the context of newbie FWs.

\section{Methodology}

This paper places itself among the literature with its qualitative Phenomenological approach to unravel the experience of WFs in Turkey. The research aims at answering two main questions: what the dimensions of the experience of FWs in Turkey are and Why do some FWs prefer a non-Turkish boss and/or an entrepreneurial career. The researchers conducted interviews and focus groups to obtain the answers. The researchers interviewed each participant for 15-30 minutes and asked many open questions. Two focus groups were held one had 4 participants and another had three participants. The researcher found that the Individual interviews yielded more data than focus groups as people's opinions were clouded by the louder voice in among the participants. The interviews were coded and classified through (consider.ly) platform to find main trends and common points of discussion.

\section{Research Findings and Discussion}

The research findings are explained in the following three sections: Participants' demographic characteristics; FWs work experience; and Internal discrimination. 


\section{Participants Profiles}

This section includes the participant's characteristics and demographics such as gender, marital status, age, income level, the duration of living in Turkey. After the examination of the general characteristics of the participants, we found that the majority of the interviewees were males. This could be attributed to two reasons, first, the participants volunteered to participate in the research, second males have more social pressure to work as they are either supporting their families or establishing a future to have their own families, similar to the patriarchal society in Turkey (Yıldırımalp, İslamoğlu, \& İyem, 2017). When the marital status was examined; most of the interviewees were single. All the participants were Arabs (Syrians, Iraqis, Egyptians, and Palestinians). Most of the participants are students or came to Turkey to work and study. Some of them came illegally and the other came directly to study. The following table shows the demographics of the participants. The total number of interviewees was 17 due to time and resources limitations. However, more interviews to be conducted to gain a better understanding of the work experience of Arab workers in Turkey.

\section{FWs Sharing Their Work Experience}

This section starts with a discussion of how FWs share their work experiences, it also discusses what hinders them from sharing their experience.

The first interviews were conducted in the Turkish language by a Turkish moderator, then some interviews were conducted in Arabic, we noticed a shift in the attitude and the details of the shared narratives that were given when the participants spoke in their mother tongue and this is why we decided to proceed with the participants' native language to give them a safer room to interpret their experiences.

The following notes were taken during the observation of a focus group that had 5 members discussing their work experience:

Table 2. Demographics of the participants

\begin{tabular}{|lc|cc|}
\hline \multicolumn{2}{|c|}{ Gender } & & \multicolumn{2}{c|}{ Age } \\
- Females & 6 & $-18-25$ & 8 \\
- Males & 11 & $-<25$ & 9 \\
& & & \\
\hline Marital Status & & Education & \\
- Single & 14 & - Student & 9 \\
- Not single & 3 & - Worker & 8 \\
\hline \multicolumn{2}{|l|}{ Nationality } & & Duration of life in Turkey \\
- Syrian & 5 & $-0-3$ years & 7 \\
- Iraqi & 5 & $-3-5$ years & 8 \\
-Palestinians & 5 & $-5-7$ years & 2 \\
- Other & 2 & & \\
\hline Work experience type & & \\
- White-collar & 10 & & \\
- Blue-collar & 7 & & \\
&
\end{tabular}

"The body language of the participants indicated a closure and tendency to not share more than what they have been asked. Arms were crossed and for the first 15 minutes the discussion was robotic, the answers were standardized, the interviewer understood that the focus group will not yield any useful insights if it proceeds the same way and he started to ask questions regarding their daily lives and their home countries. At that time the participants' body language started to shift for a more positive one and they started to share more but not very detailed accounts."

The conversation occurred in Turkish_a second language for all the participants. At different points, the participants asked each other about the meaning of some words. The question would be quickly and didn't affect the flow of the conversations. The participants discussed how they are grateful to live in Turkey despite the discriminatory situations they lived through. They mentioned that foreigners usually get paid less than their counterpart Turkish employees. One of the guys shared the main challenge he faced was that the customers avoid talking to him and they assume that he is useless. The participant explained furiously:

"Even though I am fluent in the language and I have been here for four years, some customers tell me to get them a Turkish person. I feel that they [Turks] don't differentiate between being a foreigner and being stupid."

His words were nodded by all of the participants indicating that they had either faced something similar or had heard about similar situations. Some of the participants discussed that they prefer to work with foreign managers as a way out of all the challenges they faced. This also got the approval of everybody and one said:

"Whenever someone asks me about working in Turkey I tell them to avoid working with the Turks"

The laughter followed his statement. And approving nods filled the room. This attitude could be one of the main drivers of the entrepreneurial tendencies of the FWs who came as students or refugees and then decided to establish a life in Turkey as a better alternative to their usually war-torn home countries. The discussion about how hard it is to get a work permit was in line with the findings of other research (Kizil, 2016) and was repeated by different participants who were promised to get work permits and worked with a low payroll to only be faced with broken promises from their employers. In one account the participant shares:

"After graduation and spending more than five years in Turkey I wanted to capitalize on my time in Turkey by getting the nationality. So I started working in different places that promised to issue a work permit for me... After talking to different people, I figured out that they are not going to issue me a work permit. It was biased and they would issue the work permit for very few people who are selected based on the boss liking of them and had nothing to do with the work quality nor commitment. The work permit is a myth they tell the employees to make them agree to low salaries"

Most of the participants especially the students talked about their aspirations and hope to defy the odds of the difficulty of finding a formal job in Turkey. This agrees with the findings of Kizil (Kizil, 2016) in which they found that "qualified workers will seek better and legal jobs sooner or later".

The workers who worked in blue-collar jobs worked in bad conditions and low page talked about that they chose to not think about their life and reflect upon it at that time because they had to work to survive and thought that worrying about the quality of work and life is such a luxury. One of the participants worked on a cow's farm for a year and even slept on the farm for six months before moving to shared housing. Then he rotated in many jobs to support his 
"It was normal, I didn't think of it, I only knew that I had to support my mother and siblings, at that time I forgot about studying. Then my father came, thank god, he sold our piece of land and came. He too came illegally. When he came, I heard about an Arabic school in Sakarya, so I decided to enter the general exam to be able to join the university. So, I started to study and work at the same time."

In general, mobility between jobs for FWs is decided by pay wage only. Jobs are usually found through referrals and acquaintances. Participants who had experience in white-collar jobs, they stated that they faced little to no discrimination and that they were treated based on their skills and performance. Discussing his work experience in a furniture workshop one of the participants detailed that he was treated as his colleagues saying that "I never felt like a foreigner".

However, they experienced dishonesty regarding future promises regarding the issuance of work permits and some level of exploitation. The main challenges regarding the workplace mentioned by the participants included: working conditions, lower wages, and longer working hours in comparison with the Turkish workers, working without social security benefits. which aligns with the same as the results of (Tören, 2018) on the effects of the Syrian refugees on the labor market.

Another alarming and repeatedly mentioned work experience challenge stemmed from the different working styles and values between the home country of the FWs and the Turkish employer was the use of "this is how it goes in Turkey" by the Turkish manager to impose his different working style without providing a decent explanation or attempting to listen to the reasons behind the way the FWs does the job. One of the participants described as:

"...every time we disagree with a manager on something he would say "this is how it is in Turkey" and he talks as if I had never worked with Turkish people before and as if I had no knowledge of how things work in Turkey, but I knew that he says that to only do what he sets his mind to. He was exploiting the fact that we are foreigners, but he was not racist."

Different working styles and values exist between the workplaces in Turkey and the origin country of the FWs. There is a Tendency of Turkish manager to using "this is how it goes in Turkey" to impose his different working style on FWs.

In this section we discussed the conditions of a safe environment for FWs to discuss and talk about their experiences, we found that when eliminating the translation factor and speaking with the FWs in their mother tongues the conversations were more productive and they shared more details about their work experience. We also discussed in this section the entrepreneurial tendency of the FWs and their preference for not working with Turkish managers due to a myriad of reasons such as the cultural differences and work culture differences. We found that there is no discrimination in white-collar jobs however there is a level of exploitation.

\section{The Inter-Racism and Inter-Discrimination Phenomena}

The analysis of the collected data shed the light on one of the challenges that blue-collar FWs face when they start working in Turkey which the researchers named "internal-discrimination". The researchers define "Internal discrimination" as a type of discrimination that describes the exploitative and discriminatory practices that some people engage in against people from the same country due to a lack of specific skills in an abroad workplace. They noticed that the major factors that encourage this behavior are the language barrier as many FWs lack language skills as well as the desperate need for money to sustain a living. Internal discrimination seems to affect the experience of FWs in Turkey significantly negatively. One of the participants in the study shared:

"I felt that there was a subtle inter-racism and egoistic attitudes between Iraqis and Syrians. Which is weird given that both immigrants fled the war. The general stereotype is that Syrians are generally more skilled and educated than Iraqis, and Iraqis are richer than Syrians. The stereotype seems to affect the experience of the foreign workers as they start working with preexisting attitudes that vary from the workers feeling that they are "more skilled", "smarter", "deserve better"."

It seems that the internal bullying and exploitation was the main source of misery for some of the participants as they were traumatized and shocked that people from the same country and religion would engage in exploiting them and making their already hard life harder.

The disbelief and psychological pain from internal bullying and exploitation were unbearable. The language barriers stood before the FWs to complain about the inter-discrimination and bullying they were facing. One of the participants talked about his experience speaking up against internal bullying through using an online translation application, he wrote a letter and gave it to his Turkish manager who quickly responded and took measures against the bully and supported the FW.

In this section, we discussed the internal bullying and the internal discrimination that FWs face while working informally and when they do not know the Turkish language. The people who are engaged in the internal-discrimination and bullying work as "job dealers" in which they take money or part of the wage from the people who need a job and cannot find in their own because they are new to the country or city and they do not know the language.

\section{Conclusion}

Turkey is a destination for many foreign workers from different countries from around the world due to its location in the heart of the world. The rise of populism and ultra-nationalism in Turkey and around the world makes it imperative to study the experience of the FWs. In this study, we focused on the experience of FWs in Turkey. They face many challenges with the language being the main obstacle. Our research found that there is no direct discrimination, but differences that stem from cultures and ethnicities are mismanaged. We found that "Inter-racism" and inter-discrimination between the FWs and people from their countries who provide them with work to have a significant effect on the experience of the FWs who are new in Turkey and are not able to speak Turkish. The researchers define "Internal discrimination" as a type of discrimination that describes the exploitative and discriminatory practices that some people engage in against people from the same country due to a lack of specific skills in an abroad workplace.

\section{Research Limitations and Future Studies}

The participants of the research are living in Sakarya, Eskisehir, and Istanbul cities that do not have recorded discrimination and high influx of FWs as in Gaziantep, Hatay, and other border cities. Future researches need to include more cities.

\section{References}

Favell, A., Feldblum, M., \& Smith, M. P. (2007). The human face of global mobility: A research agenda . Transaction social science and society . Araci, D. T. (2018). Evaluating the impact of Syrian refugees on Turkey's labor market: A synthetic control approach. Boğaziçi University. Atik, O. (2012). Cultural differences and satisfaction of expatriates in multi-national companies.

Aydin, E. (2009). Formel ve enformel sektör ücret farkliliklari: Katmanli işgücü piyasasi kuraminin türkiye emek piyasasina uygulanmasi. 
Balkir, C., \& Böcker, A. (2015). A comparison of residence, social security and citizenship strategies of Turkish Return Migrants and Dutch Retirement Migrants in Turkey. Retrieved 12 28, 2019, from https://repository.ubn.ru.nl/handle/2066/140721

Ceritoglu, E., Yuncule, B. G., Torun, H., \& Tumen, S. (2017). The impact of Syrian refugees on natives'labor market outcomes in Turkey: evidencefrom a quasiexperimental design. IZA journal of labor policy .

de Castro, A. B., Fujishiro, K., Aweitzer, E., \& Oliva, J. (2016). How immigrant workers experience workplace problems: A qualitative study . Archives of Environmental \& Occupational Health, 249-258.

İçduygu, A. (2013). Turkey And International Migration, 2012-13. Istanbul: Migration Research Center At Koc University.

Kizil, C. (2016). Turkey's policy on employment of Syrian refugees and its impact on the Turkish labour market. In D. Eroğlu, J. H. Cohen, \& I. Sirkeci, Turkish Migration 2016. London: Transnational Press London.

Rittersberger-Tılıç, H. (2015). Managing' irregular labor migrants in Turkey. The Journal of Migration Studies .

The general directorate of international labour force. (2017). Labor Statistics. Ankara.

Tören, T. (2018). Syrian refugees in the Turkish labour market. kassel university press GmbH.

Tumen, S. (2016). The economic impact of Syrian refugees on host countries: Quasi-experimental evidence from Turkey. American Economic Review: Papers \& Proceedings.

Turkish Statistics Instutute. (2019). Istanbul.

Yıldırımalp, S., İslamoğlu, E., \& İyem, C. (2017). Suriyeli sığınmacıların toplumsal kabulve uyum sürecine ilişkin bir araştırma. V. International Balkan and Near Eastern Social Sciences, (pp. 107 - 126).

Yildiz, G. B. (2007). Foreign workers in Turkey, their rights and obligations regulated in Turkey labor market. European Journal of migration and law. 